\title{
Re-Engineering Vocational and Technical Education for Sustainable Development in North Central Nigeria
}

\author{
Abayomi Olumade Sofoluwe ${ }^{1}$ \\ ${ }^{1}$ University of Ilorin [E-mail: aosofoluwe@ unilorin.edu.ng]
}

\begin{abstract}
Using the case of North Central Geo-Political Zone of Nigeria, this study interrogates the nexus between vocational and technical education (VTE) and sustainable development. Specific attention is put on provision and attainment of basic skills on one hand and job creation, self-employment, utilization of locally available resources, provision of technology and capital formation on the other hand. Data were collected from a stratified random sample of 36 out of the 98 schools in the region. The data were collected using a VET Sustainable Development Questionnaire (VTESDQ). Four hypotheses were tested at the .05 level of confidence using Pearson Product Moment Correlation. The findings were that VTE significantly affects sustainable development. It is recommended that: 1) the content of VTE be related to the requirements of the labour market; 2) VTE institutions be established close to the rural populace; and 3 ) the study programmes VTE institutions offer reflect the community's culture.
\end{abstract}

Keywords: Vocational and Technical Education; Sustainable Development

\section{$1 \quad$ Introduction}

UNESCO (2000) defined VTE as the aspects of educational process involving, in addition to general education, the study of technologies and related sciences and the acquisition of practical skills, attitudes, understanding and knowledge relating to occupation in various sectors of economic and social life. FGN (2004) conceptualized VTE as education given in institution as providing both scientific knowledge and practical skills required for a specific trade, employment or profession as craftsman, technicians/-technologists and scientist of similar levels in business field of engineering and applied science. It refers to the aspect of education, which leads to the acquisition of practical and applied skills are well as basic scientific knowledge. Denga (1983) in Ameh (2002) defined Vocational and Technical Education as "any form of education which 
sufficiently prepares an individual to perform in his chosen occupation. He further expatiated by saying it teaches skill, develop attitudes and competencies that are requisite to success in any given occupation. Similarly Olaitan (1985) in Ukula (2002) conceived Vocational and Technical Education as a highly useful education as its occupation content is such that the trainee acquires skills, attitudes, interest and knowledge to perform socially and economically work that is beneficial both himself and the society. Again, Nwosu and Igwe (1995) in Elaigwu (2002) view Vocational and Technical Education as the study of technology and related science and acquisition of practical skills, attitudes and knowledge relating to occupations in the various sectors of the economic and social life. In a nutshell, Vocational and Technical Education is the acquisition of certain relevant skills, attitudes and aptitudes under tutors of gainful employment and proper integration into the society.

In Nigeria, VTE constitute two sub-sectors which are characterized by their purposes, levels of institutions, course offerings, organisation and control. The three types of institutions distinguishable in the technical education sub-sector include: Polytechnic or Colleges of Technology, Monotechnics (Monodisciplinary, tertiary colleges and colleges of education. The hierarchical status and roles of the institutions in the national education system is as indicated below:

\begin{tabular}{lll}
\hline Level & Institution Type & Primary Manpower Production Level \\
\hline Tertiary & $\begin{array}{l}\text { University } \\
\text { Polytechnic/ Monotechnic } \\
\text { Colleges of Education } \\
\text { (Technical) }\end{array}$ & $\begin{array}{l}\text { Professional (i.e. high level manpower) } \\
\text { Technologists and Technician (i.e. } \\
\text { Middle Level Manpower). }\end{array}$ \\
& & $\begin{array}{l}\text { Technical (middle) level technical } \\
\text { teachers }\end{array}$ \\
Secondary & Technical College & $\begin{array}{l}\text { Craftsmen and Master Craftsmen (i.e. } \\
\text { Low level Manpower). }\end{array}$ \\
Post- & Business and Engineering & $\begin{array}{l}\text { Operatives and Artisans (i.e. Low Level } \\
\text { Primary }\end{array}$ \\
Primary & Skills Training & Manpower). \\
& Primary-School & Basic Education \\
\hline
\end{tabular}

\subsection{Mission of VTE}

The $2^{\text {nd }}$ International Conference on VTE held in Korea 1999 set the mission for all nations under UNESCO to use VTE to address the employment and or other socio-economic challenges of the $21^{\text {st }}$ century. These challenges include globalization, political integration, trade liberalization, an ever changing technological scenario, ICT revolution and the consequent rapid pace of social change. UNESCO (2000) concluded that VTE shall therefore produce, through 
the institution of entrepreneurial education, more job creators than job seekers. The Mission of the VTE as stated are as follows:

- To eliminate unemployment by equipping the generality of out of school youths and adults with saleable skills.

- To infuse into all adequate vocational efficiency for effective living.

- To enhance and sustain national economic and technological development.

- To engender national economic prosperity.

In fulfilment of the mission, the Federal Government of Nigeria (2004) set up to:

- Expand the productive base of the economy through increased agricultural and industrial production.

- Develop new infrastructural facilities and rehabilitate existing ones to provide conducive environments for private investment.

- Lay a solid foundation for self-reliant economy through technological development; and reduce the level of unemployment through the creation of ample opportunities for gainful employment.

For the purpose of National Development, the policy prescribes the following four objectives for all types and levels of education.

- The inculcation of national consciousness and national unity.

- The inculcation of the right type of values and attitudes for the survival of the individual and the Nigerian Society.

- The training of the mind in the understanding of the world around; and

- The acquisition of appropriate skills abilities and competencies both mental and physical as equipment for the individual to live in and contribute to the development of the society.

- Nigeria is fast evolving through the operation of its 6-3-3-4 educational system a three stream system of curricula offerings. It is now easy to stream curricula as liberal arts based, science based and technology based from the senior secondary level. This streaming, indeed, facilitates educational management particularly in regard to the provision of facilities, curricula development, career education, teacher training and institutional management.

\subsection{Development of VTE in Nigeria}

The origin of vocational and technical education in Nigeria could be traced to the pre-colonial era when traditional education was in practice. During the period, the child was trained in the family trade by direct apprenticeship to either the parents or relations. According to Ogunmila (2006), in traditional 
education of the various ethnic nationalities, arts and crafts of various types have existed as their own expression of vocational training; while traditional agricultural practices have been developed to suit the cultivation of the agricultural species predominantly produce in the different eco-geography areas of the country.

In the early part of the colonial period, vocational training was not encouraged. Schools were built primarily for the purpose of evangelism by the early missionaries. The early missionary was characterized by literacy type of education which was geared towards winning converts and producing clerks and interpreters (Ajayi and Ayodele, 2002). It was not until 1908 that government department started to organize some form of vocational training school in 1908,the marine training school in 1928 and the public works, the post and telegraph and railway training school in 1931(Adegbile, 2000). Government active participation in the provision of technical education became obvious between 1930 and 1960. Yaba Higher College was officially opened on January 19, 1934. Technical colleges were established by various regional governments in Enugu 1950, Ilorin 1951, Kano 1953, Bukuru 1953, Sapele 1955, Ijebu-ode 1959, Osogbo, Oyo 1961, Owo 1963, Aba 1964 and Abakaliki 1966. These colleges were not fee paying and they were adequately funded by the government.

In 1959, Federal Ministry of Education (Nigeria) appointed a commission to conduct an investigation into Nigeria's needs in the field of Post-Secondary Education in Nigeria. The reports (Ashby) recommended that adequate attention should be given attention to technical and vocational education, encourage students to study technical drawing and craft subjects and upgrade the technical schools courses to the award of City and Guilds of London.

The Comparative Technical Education (1963) recommended three levels of vocational and technical education as:

- Pre-vocational and pre-technical training usually offered in secondary schools.

- Craftsmen training usually offered in technical colleges, trade centres and vocational schools.

- Technical training usually offered in polytechnics and colleges of technology.

The Fourth Commonwealth Education Conference (1986) recommended that industry should be closely associated with technical education and through policy-making, manpower planning, and curriculum development, provision of opportunities for industrial experience, accreditation, consultancy services, part-time courses and vocational guidance. 
In 1987, the National Council on Education (NCE) approved National Board for Technical Education (NBTE) for broad classification of vocational and technical institutions into:

- Vocational Schools - These are made up of vocational/artisan training centres to produce artisans. They are post-primary level institutions that pursue courses leading to the award of the Federal Ministry of Labour and Productivity Trade Test Certificates Grade III, II \& I.

- Technical Colleges - Institution that produces craftsmen at the craft level and master craftsmen at the advanced craft level. They are post-junior secondary school institutions taking courses that lead to the award of the National Technical Certificate/National Business Certificate (NTC/NBC) and Advanced National Technical Certificate/Advanced National Business Certificate (ANTC/ANBC) for technical and business studies respectively.

- Polytechnics/Monotechnics/Colleges of Technology: These are post-senior secondary school institutions, which produce technicians and higher technicians/technologists.

The courses offered by these institutions are of two years duration, each leading to the award of National Diploma (ND) and Higher National Diploma (HND) respectively. FGN (2004) identified range of courses to be offered at VTE as mechanical trades, computer craft practice, electrical engineering trades, building trades, wood trades, hospitality, textile trades printing trades, beauty culture trades, business traders and leather goods manufacture.

FGN (2004) has good intentions for VTE programme, still, fraught with problems, including administrators' misconception of the nature of VTE, inadequate political will by the government, deficit educational monitoring and evaluation procedures, poor funding, poor incentives for teachers and problem of curriculum implementation nature of programmes being terminal rather than development. In realization of these problems, the FGN (1997) set up National Board for Technical Education through Decree No.9; The Board is empowered to coordinate technical education by setting standard for schools in terms of facilities, teaching manpower and accreditation of courses.

Consequently, there has been a phenomenal expansion in technical education. From one technical college in 1948, the country has 71 polytechnics with various programmes for pre-national diploma, national diploma and higher national diploma. Furthermore, available related literature reviewed that:

- Between the year 2000 and 2008, 9 polytechnics were established bringing the total number of polytechnics to 71 .

- The number of Monotechnics increased from 30 in year 2000 to 39 in the year 2005 . 
- Total students enrolment in Monotechnics increased from 11,227 in 2000 to 20,853 in 2005.

- In Monotechnics in 2005, the number of students that enrolled into PreNational Diploma (programme stood at 2,691 (12.9\%). Similarly, 13,425 (64.38\%) enrolled into National Diploma while the remaining 4,737 (22.72\%) enrolled into Higher National Diploma.

- In Polytechnics, total students enrolment rose from 118,216 in 2000 to 311,581 in 2005.

- In Polytechnics, students' turnout in Polytechnics rose from 51,372 in 2002 to 74,570 in 2004.

- In Technical schools, the number of technical schools increased from 159 in 2006 to 162 in 2008.

Table 1: Distribution of Educational Institutions and Enrolment (2009)

\begin{tabular}{lll}
\hline Institution Type & No. of Schools & Total Enrolment \\
\hline Primary School & 54,434 & $21,294,517$ \\
Secondary School & 18,238 & $6,625,943$ \\
- Junior School & & $3,720,789$ \\
- Senior School & & $2,905,154$ \\
Monotechnics & 39 & 20,853 \\
Colleges of Education & 83 & 343,387 \\
Polytechnics & 71 & 311,844 \\
- Pre National Diploma & & 39,488 \\
- National Diploma & & 212,225 \\
- Higher National Diploma & & 59,870 \\
\hline
\end{tabular}

Source: FGN (2009) and National Universities Commission

Therefore, technical education is a concept reserved for the education of technologists and technician cadre of manpower in all occupational fields are offered by the Polytechnic, Monotechnics and College of Education.

The Federal Government of Nigeria has good intentions for TVE Programmes. However, the programmes are still fraught with problems. In the past, Nigerian society looked down on VTE as unprofitable. There is negative perception from the society that VTE is for the "drop out", "drop in" in schools. There is general attitude, found "quick wealth or the get-rich-quick syndrome". There is still a story tendering towards white-collar job as a result of low statue associated with most kind of VTE. A lot of capital expenditure is required for the procurement of equipment. There is under estimation or over estimation of money allocated to VTE in Nigeria. VTE programmes are ill-equipped and workshops and laboratories are not adequately provided. VTE is also affected by poor planning and administration. Obayan (2002) noted that technical managers in developing countries are essentially managers who have grown 
without any technical background or training. Insufficient and poorly qualified staff. Healthy and skilled teachers are migrated lucrative ventures, which pay good salaries. This marks for most schools employing mediocre, artisans and technicians to man most sensitive subjects.

\subsection{Sustainable Development}

Sustainable development is development which meets the needs of the present without compromising the ability of future generations to meet their needs (Wikipedia 2011) It contains within it two key concepts: the concept of needs, in particular, the useful needs of the world's poor, to which overriding priority should be given; and the idea of limitations imposed by the state of technology and social organization in the environment's ability to meet present and future needs. (Brundland Report).

The definition entails that world is seemed a system, a system that connects space, and a system that connects time. Wikipedia (2011) opines that sustainable development is a pattern of resource use that aims to meet human needs while pressuring the environment so that these needs can be met not only in the present but also for generations to come. United Nations (1987) used the term sustainable development as to meet the needs of the present without compromising the ability of future generation to meet their own needs, social development, environmental protection and cultural development.

The International Union for the Conservation of Nature (IUCN) Sahel Studies (1989) sees sustainable development as involving the maximization of the net benefit of economic development, subject to maintaining or enhancing the service and quality of natural resources over time. Akorede and Onuka (2008) sees sustainable development as a way by which the society is managed in an effective and efficient manner such that it benefits all and sundry, with enough resources still available for the continuation of the human race. This is achievable through the judicious and careful use of global resources. The sustainable development seeks to promote prosperity (economic objective) through growth, equity and efficiency in all sectors of development. It seeks to support people (social objectives) through empowerment, participation of all stakeholders, social mobility, cultural identity and various institutional development. Finally in the tripod, it seeks to maintain the planet (ecological objectives) through improving the state of the ecosystem, biodiversity conservation, and ensuring adequate carrying capacity and responding in sustainable manners to other global issues. 


\subsection{Statement of the Problem}

The $2^{\text {nd }}$ international conference of VTE held in Korea in 1999 set the mission for all nations under UNESCO to use Vocational and Technical Education to address the unemployment and other socio-economic challenges of the $21^{\text {st }}$ century. These challenges include globalization, political integration, trade liberalization, ICT revolution, bring dream, social economic problems, dysfunctional aspects of the educational system and unemployment which is a global problem but it is quite alarming in Nigeria.

For the nation to be accorded as one of the leading countries in the world there is an urgent need to re-focus VTE for sustainability in Nigeria. Reasons for the re-engineering of VTE include employment and income generation, contribution to the GDP, linkage effects, fostering innovation, industrialization and technological development. Thus, the paper begins with the concept, mission, historical background, and trends in the growth of VTE. Consequently, problems, strategies for re-engineering and recommendation are finally suggested towards united, strong and self-reliant nation. It is in the light of this that this paper seek to look into re-engineering Vocational and Technical Education for sustainable development in north - Central Geo-Political units of Nigeria.

\subsection{Objectives and Hypotheses}

The general objective of the study was to examine VTE for sustainable development in North - Central Geo-Political zone of Nigeria. The specific objectives were to:

- examine whether significant relationship exist between basic skills and job creation

- investigate whether significant relationship exist between basic skills and self-employment

- examine whether significant relationship exist between basic skills and utilization of local resources

- find out whether significant relationship exist between basic skills and provision of technology

- investigate whether significant relationship exist between basic skills and capital formation

The following hypotheses were stated in line with these objectives:

- There is no significant relationship between Basic Skills and Job Creation

- There is no significant relationship between Basic Skills and selfemployment. 
- There is no significant relationship between Basic Skills and utilization of Local Resources.

\section{$2 \quad$ Methods}

The study was conducted following a cross-sectional survey design. This involved description of parameters for statistics obtained from unbiased samples involves the use of questionnaire to obtain information from a sample of respondents for testing hypotheses relevant to educational problems and enable generalization of results on the sample of the population from which it is drawn. The population of the study was made up of 98 public Secondary Schools in the North Central Geo-Political Zone of Nigeria. Thirty-six (36) out of the 98 schools were selected using stratified random sampling techniques. The total population of the study was 3,680 and a sample of 920 students was randomly selected. Data were collected using a self-constructed questionnaire that was tagged "Re-Engineering Vocational and Technical Education for Sustainable Development in North Central Geo-Political Zone in Nigeria". The sample schools were visited with the help of a research assistant who administered the questionnaire. The data were analysed using means and Pearson Product Moment tests at the .05 level of confidence.

\section{$3 \quad$ Results and Discussion}

Main hypothesis: There is no significant relationship between Vocation and Technical Education and Sustainable Development in North Central Geo political zone of Nigeria.

Table 2: VTE and Sustainable Development

\begin{tabular}{llllllll}
\hline & N & Mean & SD & Df & $\begin{array}{l}\text { Calculated } \\
\text { r-value }\end{array}$ & $\begin{array}{l}\text { Critical r- } \\
\text { value }\end{array}$ & Decision \\
\hline VTE & 920 & 41.2 & 14.7 & 918 & .193 & .042 & Reject Ho \\
$\begin{array}{l}\text { Sustainable } \\
\text { Development }\end{array}$ & 920 & 98.59 & 41.48 & & & & \\
\hline
\end{tabular}

Table 2 above revealed that the calculated r-value of Pearson product moment correlation coefficient of .193 is greater than the critical r-value of .042 at 0.05 level of significance and for 91 degree of freedom. Hence, the hypothesis is rejected. This reveals that there is significant relationship between Business Vocational Education and Entrepreneurial development in North Central Geo- 
Political unit of Nigeria. From the above it is clear that VTE can actually promote Sustainable development.

The study revealed that employment creation utilization of local resources, promotion of technology, diversification of business, capital formation and promotion of an entrepreneurial culture are variable that are capable of ensuring the use of VTE for sustainable development in Nigeria.

$\mathrm{Ho}_{1}$ : There is no significant relationship between Basic Skills and Job Creation

Table 3: Relationship between Basic Skills and Job Creation

\begin{tabular}{llllllll}
\hline & N & Mean SD & Df $\begin{array}{l}\text { Calculated } \\
\text { r-value }\end{array}$ & $\begin{array}{l}\text { Critical r- } \\
\text { value }\end{array}$ & Decision \\
\hline $\begin{array}{l}\text { Basic skills } \\
\text { services }\end{array}$ & 920 & 9.1 & 2.61 & 918 & .287 & .42 & $\begin{array}{l}\text { Reject } \\
\text { Job Creation }\end{array}$ \\
\hline Job & 920 & 98.5 & 41.48 & & & & \\
\hline
\end{tabular}

Table 3 revealed that the calculated $\mathrm{r}$-value of Pearson product moment correlation coefficient of .287 is greater than the critical r-value of 0.42 at 0.05 level of significance and for 918 degree of freedom. The null hypothesis is rejected. Therefore, there is significant relationship between job creation and sustainable development in North Central Geo Political zone, Nigeria. This is in conformity with Aliyu (2011) who sees VTE as a means of generating employment opportunities.

$\mathrm{Ho}_{2}$ : There is no significant relationship between Basic Skills and selfemployment

Table 4: Relationship between Basic Skills and Self-Employment

\begin{tabular}{|c|c|c|c|c|c|c|c|}
\hline & $\mathrm{N}$ & Mean & SD & Df & $\begin{array}{l}\text { Calculated } \\
\text { r-value }\end{array}$ & $\begin{array}{l}\text { Critical } \\
\text { r-value }\end{array}$ & Decision \\
\hline $\begin{array}{l}\text { Basic skills } \\
\text { services }\end{array}$ & 920 & 11.25 & 2.86 & \multirow[t]{2}{*}{918} & .265 & \multirow[t]{2}{*}{.42} & \multirow[t]{2}{*}{$\begin{array}{l}\text { Reject } \\
\text { Ho }\end{array}$} \\
\hline $\begin{array}{l}\text { Self- } \\
\text { employment }\end{array}$ & 920 & 98.5 & 41.48 & & & & \\
\hline
\end{tabular}

Table 4 revealed that the calculated r-value of .265 is greater than the critical rvalue of 0.42 at 0.05 level of significance. Therefore the null hypothesis which states that there is no significant relationship between Basic Skills and selfemployment is rejected. This implies that there is significant relationship between basic skills and self-employment. When there is adequate basic skill in Business Vocational Education this will have a direct bearing on Entrepreneurial development thereby making people to be self-employed. This 
is collaborated with the statement of Obike (2013) who maintained that the acquisition VTE and sustainable skills led to self-employment and poverty reduction.

Ho3: There is no significant relationship between Basic Skills and utilization of resources.

Table 5: Relationship between Basic Skills and Utilisation of Resources

\begin{tabular}{llllllll}
\hline & $\mathrm{N}$ & Mean & SD & Df & $\begin{array}{l}\text { Calculated } \\
\text { r-value }\end{array}$ & $\begin{array}{l}\text { Critical } \\
\text { r-value }\end{array}$ & Decision \\
\hline $\begin{array}{l}\text { Basic skills } \\
\text { services }\end{array}$ & 920 & 7.27 & 1.42 & 918 & .235 & .42 & $\begin{array}{l}\text { Reject } \\
\text { Ho }\end{array}$ \\
$\begin{array}{l}\text { Utilisation } \\
\text { of local } \\
\text { resources }\end{array}$ & 920 & 98.5 & 41.48 & & & & \\
\hline
\end{tabular}

Table 5 the calculated $\mathrm{r}$-value of .235 which is greater than the critical r-value of 0.42 at 0.05 level of significance and at 918 degrees of freedom. Therefore, the null hypothesis which states that there is no significant relationship between Basic Skills and utilization of Local resources is rejected. There is a positive significant relationship between Basic Skill and the utilization of Local resources. Aliyu (2011) reveals that skills associated with the manufacturing of traditional artefacts and crafts using local resources will contribute to sustainable economic development.

\section{Conclusions and Recommendations}

The central theme of this paper was the reengineering VTE for sustainable development in Nigeria. The nation has come up with plans for vocational and technical education, which, if implemented will transform the great nation to economically viable nation. Reengineering of VTE entails balanced curriculum development, NGOs community participation, improved funding, recruitment of qualified and skilled personnel, VTE schools management board, provision of adequate facilities and instructional materials and effective industrial training. The recommendations made can move the nation to a level of adequate manpower, disciplined citizenry, national integration and modern development nation.

There should be less emphasis on certificates/examinations in implementing the curricula content of various programmes. Acquisition of practical skills should be stressed on the final outcome. Orientation programmes should be carried out towards enlightening the general public on the need for their 
children to be vocationally and technically oriented in light of the pervading economic meltdown. The content of VTE must be related to the requirements of the labour market; this could be corrected by setting up an advisory council for technical colleges, polytechnics, colleges of education and university in which employers will be reoriented. Good teaching - learning environment must be provided by the educational stakeholders. These include facilities, machine, and other instructional materials.

VTE institutions should be sited close to the rural populace and their programmes should reflect the community's culture. The management of VTE Institutions should be left strictly for experts in relevant areas. The present situation where the generalists are managing the supposed technical institutions should be discouraged. In other to encourage students enrolment in VTE programmes, government should as a matter of policy, remove the dichotomy between technical institution graduates and university graduates. The compulsory introduction of entrepreneurial courses as general studies programme in Nigerian universities is a welcome idea. Private/public partnerships in the funding and management of VTE should be encouraged. These include the parents, corporate bodies and companies, international development agencies, community organization and philanthropists.

More qualified and skilled teachers should be recruited to handle vocational and technical subjects and courses in schools. Those on the job who lack the required qualification and skills should be retrained. Moreover, vocational and technical education teachers should be motivated through attractive conditionsof service in order to increase their level of productivity.

There should be a central body at the National level to manage, supervise, finance and monitor VTE in Nigeria. Similar body should be put in place at the state and local government level. The structure could be adapted as NVTEC/SVTEB/LGVTEA i.e. National Vocational Technical Education Commission, State Vocational Technical Educational Board and Local Government Vocational Technical Authority. The constitutional roles of the Federal, State and Local Government on matters relating to VTE should be respected.

To enhance the effective teaching and learning of vocational and technical education subjects and courses in schools, adequate workshops, laboratories, classrooms, essential basic tools, equipment, machines and instructional materials should be provided. There is the need to make the teaching of vocational and technical education subjects and courses more practical and this can be facilitated through adequate provision of facilities and instructional materials.

Members of the public should give more recognition to the graduates of technical colleges and polytechnics in order to stimulate the interest of students in vocational and technical education. Furthermore, parents should encourage 
their children to offer subjects and courses in vocational and technical education as viable alternative to subjects and courses that only prepare graduates for white-collar jobs that are grossly inadequate in the labour market.

Vocational and technical education programmes should be restructured to allow the students to continue their studies up to post graduate level by removing apparent discontinuities in the structure. This can be done through the articulation of vocational programmes in the technical colleges with the ones in the polytechnics and the articulation of the technician or technologist (HND) programmes with the corresponding degree programmes of the universities.

There is the need to make students' industrial training more effective through the inculcation of entrepreneurship skills to complement the vocational and technical skills acquired by them. This will make them more relevant, functional and self-employed in their areas of specialization after graduation.

\section{References}

Adegbile, P. O. (2000). Technical and vocational education in Nigeria. A critical analysis. Paper presented at the seminar on TVE in Nigeria. Abuja Nigeria.

Ajayi, I. A. (2007). Towards the delivery of qualitative vocational and technical education in Nigeria. A paper presented at the International Conference organised by NAEAP, held at University of Lagos, Akoka $24^{\text {th }}-27^{\text {th }}$ Sept.

Ajayi, I. A. \& Ayodele, I. B. (2002). History and development of education. Ado-Ekiti: PETOA.

Akorede, S.F. \& Onuka, A.O. (2008). Managing gender and youth education for sustainable development in Nigeria Journal of Educational Administration and Planning (NAEAP) 8(1), 95-107

Aliyu, A.M (2011). Actualizing vision 20/2020 through TVET. New Nigerian, Friday October 2, 2011 2, 2011 page 8.

CSE UNESCO (1993). Proceeding of the international symposium on technical and vocational education. Beijing, China 13-18 September. 1993

Federal Government of Nigeria (2000). Blueprint on master of plan; on TVE. Abuja: Federal Ministry of Education

Federal Republic of Nigeria (2004). National policy on education. Lagos: NERC

Federal Republic of Nigeria (2009). Social Statistics in Nigeria. Abuja: National Bureau of Statistics

Joint Admission and Matriculation Board (2010) Guideline for admission on first degree course in Nigerian universities. Abuja: JAMB Secretarial

National Board for Technical Education (1997). Annual Report Kaduna NBTE 
Obayan, P. A. I. (2002). Education as a catalyst for human development in Nigeria. Paper delivered at the seminar on Human Capital Development of the Manuenian Society of Nigeria. Lagos.

Obike, U (2003). Technical vocational education as remedy for unemployment. Daily Trust Thursday April 18, 2013 page 33

Olaitan, S. O. (1996). Vocational and technical education in Nigeria. (Issues and analysis). Onitsha: Noble Graphics

Oni, G. S. (2006). Vocationalism in Nigerian education. Journal of Social Science, 12. (2), 147 - 150.

Sofoluwe, A. O. (2002). Refocusing university education in the $21^{\text {st }}$ century. In S. O. Oriafor, P. O. E. Nwankolo \& G. C. Igborbgor (Eds). Refocusing Education in Nigeria. Abraka. Faculty of Education, Delta State University, Abraka, Delta State, Nigeria.

UNESCO (1979). Development in technical and vocational education: A comparative study. Paris UNESCO.

UNESCO (1999). International conference on technical education. South Korea

UNESCO (2000). The state of education in Nigeria. Abuja Office: UNESCO

Wikipedia (2011). Sustainable development. Retrieved 5/3/2011. from://wikipedia.org/wiki.

World Bank (2000). African development indicators. Washington DC. 